\title{
Diagnosing plant water status as a tool for quantifying water stress on a regional basis in Mediterranean drylands
}

\author{
Moreno Vertovec ${ }^{\mathrm{a}}$, Serdal Sakçali ${ }^{\mathrm{b}}$, Munir Ozturk ${ }^{\mathrm{b}}$, Sebastiano Salleo ${ }^{\mathrm{a}, *}$, \\ Paola Giacomich ${ }^{a}$, Enrico Feolia, Andrea Nardini ${ }^{\mathrm{a}}$ \\ a Dipartimento di Biologia, Università degli Studi di Trieste, Via L. Giorgieri 10, 34127 Trieste, Italy \\ ${ }^{b}$ Department of Biology, Fatih University, Buyukcekmece, 34900 Istanbul, Turkey
}

(Received 17 May 2000; accepted 24 August 2000)

\begin{abstract}
This study reports measurements of stomatal conductance, relative water content and water potential $\left(\Psi_{L}\right)$ from three dominant evergreens (Ceratonia siliqua L., Quercus coccifera L. and Olea oleaster Hoffmgg. et Link) growing in four coastal sites of Turkey. In particular, a fully vegetated site $(\mathrm{H})$ was selected and compared for the above parameters to three degraded sites (D1, D2 and D3) with decreasing vegetation covers. From the integral of the diurnal time course of $\Psi_{L}$, the water stress impact on each species (WSIS) was calculated. C. siliqua and Q. coccifera showed similar WSIS's, increasing significantly from H to D3. O. oleaster was sensitive both to summer drought and to increasing site degradation. The impact of water stress was scaled up from the species to the vegetation level (WSIV) as WSIV $=\Sigma$ WSIS $_{\mathrm{S}}\left(1-f_{\mathrm{s}}\right)$ where $f_{\mathrm{s}}$ was the relative frequency of the species studied. WSIV was rather sensitive to the impoverishment of vegetation and was correlated to vegetation density as estimated both by field observations and remotely sensed Normalized Difference Vegetation Index.
\end{abstract}

desertification / leaf water potential / Mediterranean evergreens / Normalized Difference Vegetation Index / water stress impact

Résumé - Diagnostiquer l'état de l'eau dans la plante : un outil pour quantifier le stress hydrique au niveau régional dans les régions sèches méditerranéennes. Cette étude rapporte les mesures de conductance stomatique, de la teneur relative en eau et du potentiel hydrique $\left(\Psi_{\mathrm{L}}\right)$ d'arbres à feuilles persistantes (Ceratonia siliqua L., Quercus coccifera L. et Olea oleaster Hoffmgg. Et Link) croissant sur 4 sites côtiers de Turquie. En particulier, un site totalement recouvert de végétation $(\mathrm{H})$ a été sélectionné et comparé, pour les paramètres ci-dessus, à 3 sites dégradés (D1, D2 et D3) ayant une couverture végétale de plus en plus faible. A partir de l'intégrale de $\Psi_{\mathrm{L}}$, pour le cycle diurne, l'impact du stress hydrique de chaque espèce (WSIS) a été calculé. C. siliqua et $Q$. coccifera montrent des WSIS similaires, augmentant significativement de H à D3. O. oleoaster a été sensible à la fois à la sécheresse estivale et à l'accroissement de la dégradation du site. Un changement d'échelle, du niveau de l'espèce à celui de la végétation, a été réalisé pour l'impact du stress hydrique (WSIV) par la transformation WSIV $=\Sigma$ WSISs $\left(1-f_{\mathrm{s}}\right)$ ou $f_{\mathrm{s}}$ est la fréquence relative de l'espèce étudiée. WSIV est particulièrement sensible à l'appauvrissement de la végétation et est corrélé à la densité de la végétation estimée à la fois par des observations aux champs et par l'indice normalisé de différentiation de la végétation par observation satellitaire.

désertification / potentiel hydrique des feuilles / arbre à feuilles persistantes méditerranéen / index normalisé de différentiation des espèces / impact du stress hydrique

* Correspondence and reprints

Tel. +39040 6763875; Fax.+39040 568855. e-mail: salleo@univ.trieste.it 


\section{INTRODUCTION}

Today, most Mediterranean countries have to face progressive degradation of their vegetation cover due to increasing anthropic pressure $[13,31,33,57]$ leading to improper use of resources. Overgrazing, repeated fire events and indiscriminate urbanization are common factors [21,32] contributing to impoverishment of Mediterranean forests and grasslands and, hence, to increasing environmental aridity.

Whenever evapotranspiration increases beyond given limits, water availability to plants becomes insufficient to sustain the transpirational and physiological demand and water stress develops in plants; these plants then react by reducing gas exchange and, hence, $\mathrm{CO}_{2}$ fixation and productivity $[11,29,55]$. A problem arising when large areas are considered in this regard, is how to quantify the impact of water stress on a regional scale, based on the response of a few individuals of a single or several species. The aim of such scaling exercises are to: a) discriminate drought resistant from vulnerable species; b) select the species more suitable for reforestation and/or cultivation; c) derive an index describing the impact of water stress on plant and system processes; and d) use such an index to assess larger scale trends and patterns (i.e. degradation, recovery, etc.).

Water stress is usually estimated in terms of plant water relations parameters such as leaf relative water content (RWC), water potential $\left(\Psi_{\mathrm{L}}\right)$ and conductance to water vapour $\left(g_{\mathrm{L}}\right)[2,42,47]$ as well as in terms of loss of hydraulic conductance $\left(K_{\mathrm{WL}}\right)$ of the soil-to-leaf pathway $[25,30]$. In spite of some known limits in the interpretation of pressure chamber-derived $\Psi_{\mathrm{L}}$ measurements $[14,51,59], \Psi_{\mathrm{L}}$ is easily and rapidly measured in the field and provides a reliable measure of plant water status, especially for comparative purposes. Nonetheless, field measurements of $\Psi_{\mathrm{L}}$ require some caution in their use. Common reference parameters used to estimate the extent to which plants suffer water deficit stress are predawn leaf water potential $\left(\Psi_{\mathrm{pd}}\right)$, minimum diurnal leaf water potential $\left(\Psi_{\min }\right)$ and maximum diurnal water potential drop $\left(\Delta \Psi=\Psi_{\mathrm{pd}}-\Psi_{\min }\right)$ [43]. In turn, wholeplant hydraulic conductance $\left(K_{\mathrm{WL}}\right)$ is usually estimated in terms of the Ohm's law analogue i.e. as:

$$
K_{\mathrm{WL}}=E_{\mathrm{L}} /\left(\Psi_{\text {soil }}-\Psi_{\min }\right)
$$

where $E_{\mathrm{L}}$ is the transpiration rate and $\Psi_{\text {soil }}$ is the soil water potential, usually assumed to be in equilibrium with $\Psi_{\mathrm{L}}$ when measured as $\Psi_{\text {pd }}$ [58].

The significance of both $\Psi_{\mathrm{pd}}$ and $\Psi_{\text {min }}$ as indicators of plant water status has been questioned. As an example, $\Psi_{\text {pd }}$ has been reported not to coincide with soil water potential $[3,8,43]$ during dry periods due to an air gap between roots and soil [53]. In other cases (e.g. in Eucalyptus grandis Hill ex Maiden [5]) plants lose significant amounts of water in the night so that $\Psi_{\mathrm{pd}}$ no longer equilibrates with $\Psi_{\text {soil. }}$. In turn, $\Psi_{\text {min }}$ provides useful information of whether leaves reach their turgor loss point $\left(\Psi_{\text {tlp }}\right)$ at which growth is stopped [18, 47, 60] or the cavitation threshold $\left(\Psi_{\text {cav }}\right)$ at which whole-plant hydraulic conductance is reduced due to xylem embolism [6, 52]. Nonetheless, mere $\Psi_{\text {min }}$ measurements are unable to give information of the true impact of water stress on plant growth and productivity. This is because it is the duration of the minimum levels of $\Psi_{\mathrm{L}}$ that determines the extent to which plant growth is limited. In other words, the longer the time plant organs remain at low water potentials, the greater the likelihood of damage to living cells and of extensive xylem embolism [29].

More detailed information of the impact of water stress on plants might be provided by the entire diurnal time course of $\Psi_{L}$, expressed in the integrated form as suggested by Mishio and Yokoi [23] or:

$$
\text { WSIS }={ }_{t_{\mathrm{o}}}^{t_{\mathrm{x}}} \Psi_{\mathrm{L}} \cdot \mathrm{d} t
$$

where WSIS is the impact of water stress on individuals of a given species and $\mathrm{d} t$ is the time interval when $\Psi_{\mathrm{L}}$ measurements are performed (usually between pre-dawn, $t_{0}$, and sunset, $t_{\mathrm{x}}$ ). In this form, diurnal changes of leaf water potential can be used to estimate the amount of the "environmental pressure" exerted on plants by water stress [23].

The present study reports measurements of water relations parameters in woody species dominant in different sites of the Mediterranean coastal area of Turkey. Sites were chosen to reflect increasing degradation of the vegetation cover (see below). The specific objectives of our study were to: a) quantify the impact of water stress on three different Mediterranean evergreen sclerophylls as typical components of vegetation of Mediterranean drylands; and b) assess the reliability of a relatively easily measured ecophysiological parameter to estimate the degree and duration (or intensity) of water stress. A secondary objective was to evaluate the use of remotely sensed spectral vegetation indices such as NDVI (Normalized Difference Vegetation Index) to estimate vegetation density.

To this purpose, a reference area was selected in the Dilek Yarimadasi Milli Park, characterized by optimal development of vegetation cover. Three more areas were added to the study, with decreasing vegetation cover. In all the study sites, three typical Mediterranean evergreen sclerophylls $[9,24]$ were selected i.e. Ceratonia siliqua L. 
(Carob tree), Quercus coccifera L. (Kermes oak) and Olea oleaster Hoffmgg. et Link (wild olive tree).

\section{2, MATERIALS AND METHODS}

\subsection{Description of study sites}

Four study sites were selected in two different regions of Turkey (figure 1a) i.e. in the Dilek peninsula (figure $1 b$ ) and in the Mersin State (figure 1c). In particular, the reference site was selected in the northern part of Dilek Yarimadasi Milli Park, near the city of Güzelçamli $\left(37^{\circ} 41^{\prime} \mathrm{N}, 2^{\circ} 08^{\prime} \mathrm{E}\right.$, altitude $\left.30 \mathrm{~m}\right)$ showing optimal, undisturbed development of vegetation consisting of several woody species among which the evergreen sclerophylls $C$. siliqua, $Q$. coccifera and $O$. oleaster were dominant. This site was considered as "healthy" (site H, figure $1 b$ ) and taken as a reference status of vegetation in comparison with the other three "degraded" sites (sites $\mathrm{D}$, figures $1 b$ and $1 c$ ). These, showed decreasing development of vegetation cover because of concurrent effects of climatic factors and anthropogenic pressure. Site D1 (figure 1c) was located along the coastal area of the State of Mersin, near the city of Kuyuluk ( $36^{\circ} 46^{\prime} \mathrm{N}, 34^{\circ} 31^{\prime} \mathrm{E}$, altitude $3 \mathrm{~m}$ ); site D2 (figure $1 b$ ) was located in the southern part of the Dilek peninsula, facing the coast of Karine $\left(37^{\circ} 38^{\prime} \mathrm{N}, 27^{\circ} 07^{\prime} \mathrm{E}\right.$, altitude $\left.20 \mathrm{~m}\right)$ and site D3 (figure 1c) was located in the State of Mersin, near the city of Mut $\left(36^{\circ} 34^{\prime} \mathrm{N}, 33^{\circ} 19^{\prime} \mathrm{E}\right.$, altitude $\left.270 \mathrm{~m}\right)$. In all the three D sites, the dominant species were the same as in site H (i.e. C. siliqua, Q. coccifera and O. oleaster).

Both Dilek and Mersin regions have a typical Mediterranean climate, characterized by dry, warm summers and mild, humid winters. The mean annual precipitation in the Dilek peninsula (1961-1991) is about 645 $\mathrm{mm}$. Between June and September the rainfall is as low as $20 \mathrm{~mm}$. The Mersin region is somewhat drier, with a mean annual precipitation of about $595 \mathrm{~mm}$ and about 30 $\mathrm{mm}$ rainfall during the summer period.

Measurements in site H were performed in May 1998 and repeated in September 1998. Measurements in the spring were aimed at providing reference values of the water relations parameters, because in this month plants were actively growing and water availability was likely high after winter rains. Total precipitation during March, April and May 1998 at site $\mathrm{H}$ was about $130 \mathrm{~mm}$ and air temperatures were between 15 and $25{ }^{\circ} \mathrm{C}$. In contrast, September is the driest period in the Mediterranean Basin region and therefore, represents the peak of drought stress likely suffered by plants. Measurements at sites D1, D2 and D3 were performed in September 1998, with the aim of estimating the maximum annual impact of water stress in areas at different levels of landscape degradation.

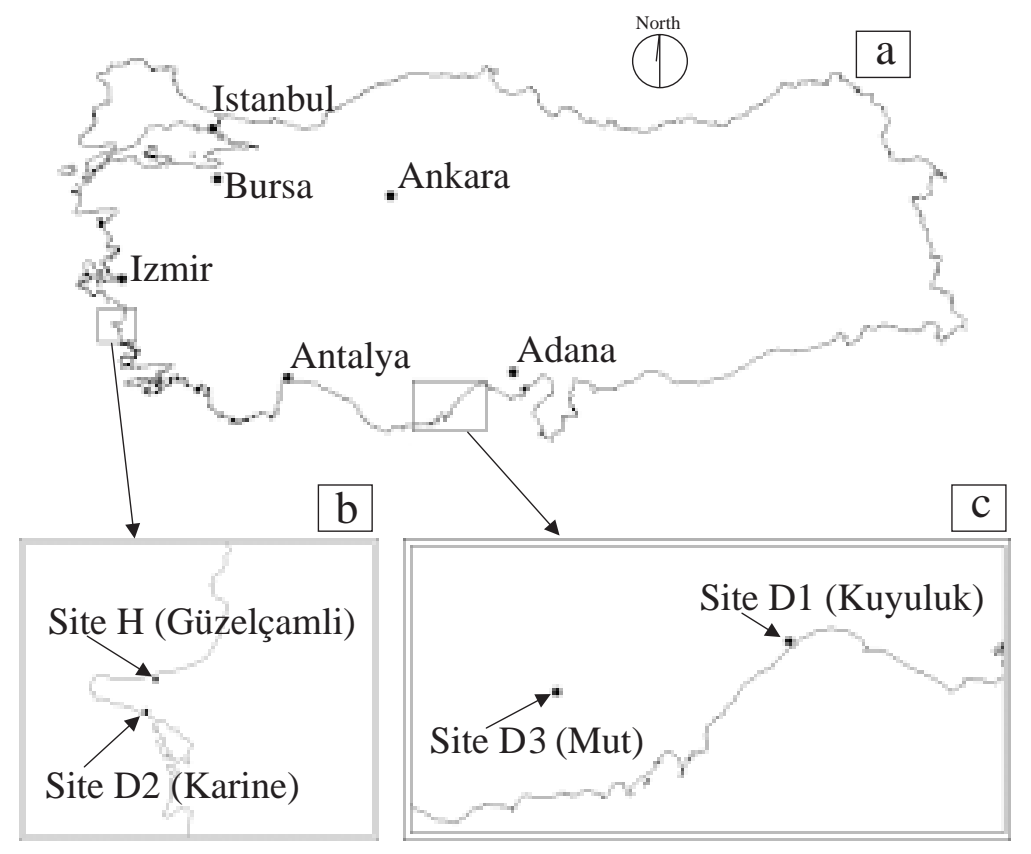

Figure 1. a) The two study areas, located in the Dilek peninsula near Izmir and in the State of Mersin, between the cities of Antalya and Adana, respectively; b) reference site $(\mathrm{H})$ near the city of Güzelçamli and degraded site (D2) near the village of Karine, both within the Dilek peninsula; c) degraded sites D2 and D3 near the city of Kuyuluk and Mut, respectively. 


\subsection{Estimating vegetation density}

Vegetation cover was estimated both by direct observations in the field and by remotely sensed satellite images. Field measurements of vegetation cover were made in September 1998. The percentage vegetation cover was estimated by laying ten $4 \times 4 \mathrm{~m}$ square quadrats in each of the four sites studied. The frequency of the three species selected was estimated by counting the number of individuals of each species growing in the selected $16 \mathrm{~m}^{2}$ areas.

Remotely sensed images were acquired from the NOAA-14 satellite equipped with the AVHRR sensor [22, 39, 54]. Images with a resolution of $1 \times 1 \mathrm{~km}$ were taken of Turkey on September 18, 1998, i.e. in the same period when field measurements of vegetation cover and water relations were performed. September 18 was a clear sunny day in all the areas selected for the study. Images were obtained from USGS (United States Geological Survey) already georeferenced and radiometrically calibrated. Images were then processed in Trieste and corrected for the atmospheric effect [22]. Channel 1 (Red reflectance, RED, $\lambda=0.58-0.68 \mu \mathrm{m}$ ) and channel 2 (Near-infrared reflectance, NIR, $\lambda=0.725-1.00 \mu \mathrm{m}$ ) were used to estimate the NDVI (Normalized Difference Vegetation Index) from the equation:

$$
\text { NDVI }=(\mathrm{NIR}-\mathrm{RED}) /(\mathrm{NIR}+\mathrm{RED}) .
$$

In this form, NDVI ranges between -1 and +1 . In particular, clouds, snow and water produce negative NDVI values. Rocky and bare soil areas result in vegetation indices near zero, while positive values of NDVI correspond to vegetated areas [16]. NDVI has been reported to provide a reliable estimate of vegetation cover and is widely used to study changes in several vegetation features such as seasonal dynamics of vegetation, tropical forest clearance, and biomass. In turn, these vegetation attributes have been used in different models to study photosynthesis, carbon budgets and water balance [16, $41,46,54]$.

\subsection{Field measurements of $g_{L}, \Psi_{L}$ and RWC}

Leaf conductance to water vapour $\left(\mathrm{g}_{\mathrm{I}}\right)$, water potential $\left(\Psi_{\mathrm{L}}\right)$ and relative water content (RWC) were measured every 90 min between 05:30 and 20:30. Measurements were repeated every $60 \mathrm{~min}$ in the time interval between 10:00 and 14:00 to provide more detailed information on minimum diurnal $\Psi_{\mathrm{L}}\left(\Psi_{\text {min }}\right)$, minimum RWC and mid-day $g_{\mathrm{L}}$. All the measurements were performed on one-year-old leaves from at least three different plants per species in May and September 1998 at site H and in September 1998 at D sites (see above).

In particular, $g_{\mathrm{L}}$ was measured on at least 20 leaves per species each daytime while still attached to the tree, using a steady-state porometer (LI-1600, LI-COR Inc., Lincoln, NE, USA). Each measurement was completed within about $30 \mathrm{~s}$. Air temperature and relative humidity were also estimated using the porometer cuvette held at about $1 \mathrm{~m}$ from the plant crown.

Relative water content (RWC) of at least 15 leaves per species each daytime was measured from different trees. Leaves were cut off while within plastic bags, placed in zip-lock plastic sacks and kept in a thermal bag at about $4{ }^{\circ} \mathrm{C}$. At the end of the experiments, leaves were brought to the laboratory and weighed on a digital balance to obtain their fresh weights (fw). Leaves were then resaturated with water to full turgor by immersing their petioles in distilled water, covering the leaf blades with plastic film and leaving them in the dark, overnight. Leaves were reweighed to get their turgid weight (tw) and then dried at $70{ }^{\circ} \mathrm{C}$ for 3 days to get their dry weight (dw). Finally, RWC was calculated as $100 \times(\mathrm{fw}-\mathrm{dw}) /$ (tw-dw).

Leaf water potential $\left(\Psi_{\mathrm{L}}\right)$ was measured on six to ten leaves per species each daytime, using a portable Scholander-Hammel pressure chamber (PMS 1000, PMS Instrument Company, Corvallis, OR, USA) [45]. All the leaves sampled grew on the southern part of the crown and were sun leaves.

\subsection{Estimating the impact of water deficit stress on single species (WSIS) and vegetation (WSIV)}

The curve describing the pattern of diurnal leaf water potential was used to calculate the integrated water stress for each species according to equation (2). In order to describe the amount of water stress suffered by the three species relative to their frequency in the different sites, WSIS was multiplied by $\left(1-f_{\mathrm{s}}\right)$ where $f_{\mathrm{s}}$ is the relative frequency of the species i.e. the ratio of the number of individuals of each species to the total number of individuals of all the three species studied. Each individual was then combined to give a weighted site stress (WSIV, water stress of vegetation) from:

$$
\begin{aligned}
\text { WSIV }= & \Sigma\left(1-f_{\mathrm{S}}\right) \cdot \text { WSIS }_{\mathrm{S}}=\left(1-f_{\mathrm{CS}}\right) \cdot \text { WSIS }_{\mathrm{CS}} \\
& +\left(1-f_{\mathrm{QC}}\right) \cdot \mathrm{WSIS}_{\mathrm{QC}}+\left(1-f_{\mathrm{OO}}\right) \cdot \mathrm{WSIS}_{\mathrm{OO}}
\end{aligned}
$$

where CS, QC and $\mathrm{OO}$ are C. siliqua, Q. coccifera and O. oleaster, respectively. 


\section{RESULTS}

\subsection{Vegetation cover and species relative frequencies}

The vegetation cover as estimated by direct field observations was 78.5, 76.5, 65.0 and $56.5 \%$ for sites $\mathrm{H}$, D1, D2 and D3, respectively (table I) whereas calculated NDVI was $0.615,0.317,0.241$ and 0.190 , respectively (figures $2 a$ and $2 b$ ). A highly significant, non-linear relationship was noted between the percentage vegetation cover and NDVI (figure 3). However, nearly equal vegetation covers estimated for sites $\mathrm{H}$ and D1 corresponded to very different NDVI's (almost double at site H versus site D1, figure 3) whereas covered changed by only $2 \%$. This was likely the effect of the dominant growth form changing from tree at site $\mathrm{H}$ to shrub at site D1 (and also D2 and D3, table I). The relative frequencies of $C$. siliqua also decreased from site $\mathrm{H}$ (about 34\%) to sites D (12 to $17 \%$ ). At site D1 (the least degraded site), C. siliqua was apparently replaced by $O$. oleaster and at sites D2 and D3 by $Q$. coccifera (table I).

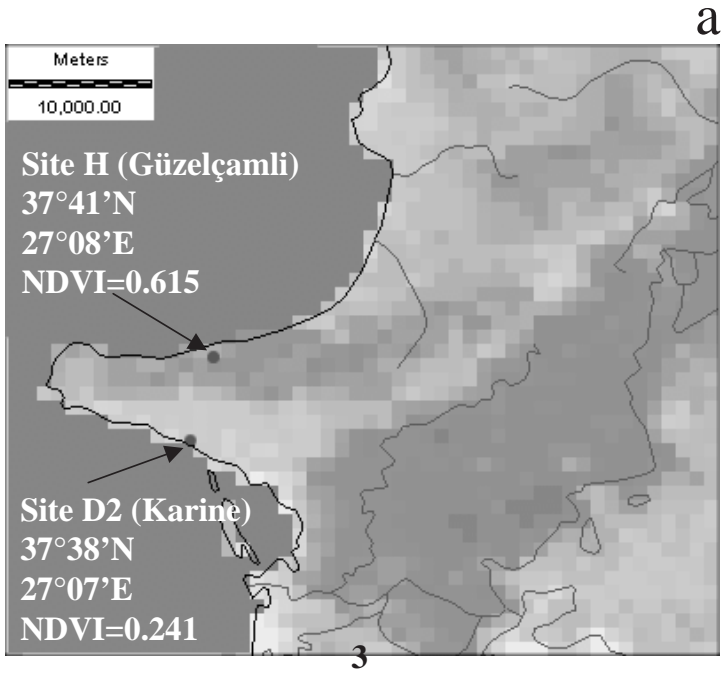

b

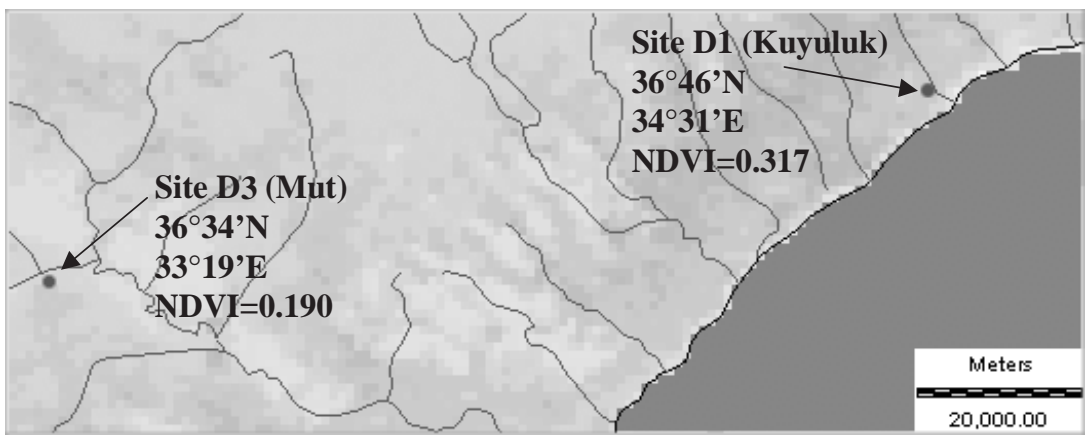

Figure 2. Images from NOAA-14 satellite. Resolution $1 \times 1 \mathrm{~km}$. For each of the four sites studied (H, D1, D2 and D3, respectively), latitude and longitude as well as the satellite derived Normalized Difference Vegetation Index (NDVI) are reported.

Table I. Percentage vegetation cover, relative frequency and growth form as estimated by field observations in a well developed vegetation site $(\mathrm{H})$ and in three degraded sites (D1, D2 and D3).

\begin{tabular}{lcccc}
\hline Site & $\begin{array}{c}\text { Vegetation } \\
\text { Cover, } \%\end{array}$ & $\begin{array}{c}\text { C. siliqua } \\
\text { Frequency / Growth form }\end{array}$ & $\begin{array}{c}\text { Q. coccifera } \\
\text { Frequency / Growth form }\end{array}$ & $\begin{array}{c}\text { O. oleaster } \\
\text { Frequency / Growth form }\end{array}$ \\
\hline H & 78.5 & 0.34 / Tree & $0.31 /$ Tree & $0.34 /$ Tree \\
D1 & 76.5 & $0.12 /$ Tree & $0.34 /$ Shrub & $0.54 /$ Shrub \\
D2 & 65.0 & 0.17 Shrub & $0.49 /$ Shrub & $0.33 /$ Shrub \\
D3 & 56.5 & $0.17 /$ Shrub & $0.49 /$ Shrub & $0.34 /$ Shrub \\
\hline
\end{tabular}




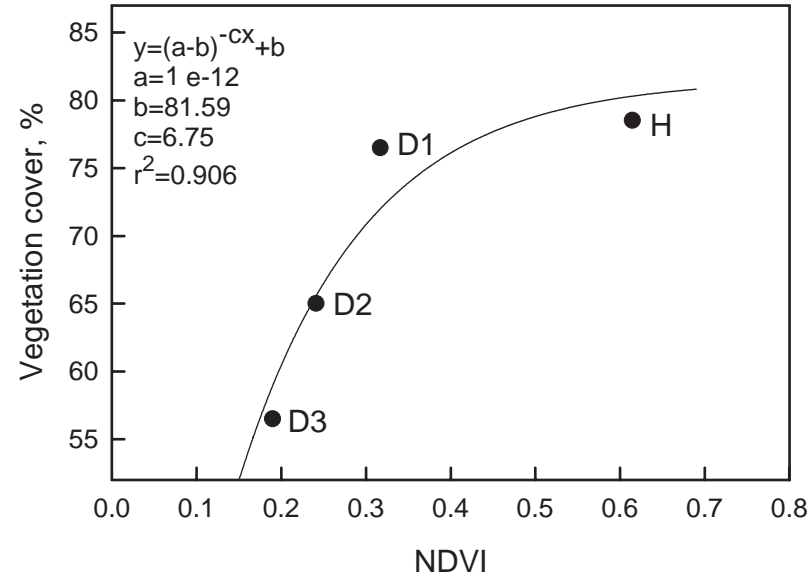

Figure 3. Relationship between percentage vegetation cover and remotely sensed Normalized Difference Vegetation Index (NDVI). The curve represents the regression line to the equation and $r^{2}$ is the correlation coefficient. Study sites are labelled as $\mathrm{H}$ (well developed vegetation site), D1, D2 and D3 (degraded sites).

\subsection{Leaf water status}

The mean of mid-day (i.e. 1000-1400 h) $g_{\mathrm{L}}$ values in the three study species for the four sites is reported in figure 4. In May, mid-day $g_{\mathrm{L}}$ 's varied between $280 \mathrm{mmol}$ $\mathrm{m}^{-2} \mathrm{~s}^{-1}$ in $Q$. coccifera and $550 \mathrm{mmol} \mathrm{m}-2 \mathrm{~s}^{-1}$ in $O$. oleaster. In September (site $\mathrm{H}$ ), both $Q$. coccifera and $O$. oleaster reduced their mid-day $g_{\mathrm{L}}$ 's (by 43 and $33 \%$, respectively), while $C$. siliqua maintained either the same or slightly higher $g_{\mathrm{L}}$ 's with respect to the spring. Mid-day $g_{\mathrm{L}}$ 's, measured in September at the three D sites, were progressively lower with respect to those recorded in the spring for both $Q$. coccifera and $O$. oleaster. A less clear pattern of $\mathrm{g}_{\mathrm{L}}$ changes was observed for $C$. siliqua where plants growing at site D2 had maximum $g_{\mathrm{L}}$ 's very close to those recorded in site $\mathrm{H}$. A noticeable reduction in maximum $g_{\mathrm{L}}$ (by about $85 \%$ ) was recorded in $C$. siliqua plants growing in the most degraded site (D3).

RWC's measured between 10:00 and 14:00 (minimum diurnal RWC's) are reported in figure 5. Leaves of C. siliqua showed minimum diurnal RWC's as high as between 90 and $95 \%$ at sites $\mathrm{H}$ and D1, and lower but still high values at sites D2 (85\%) and D3 (82\%). Similar RWC's were recorded in $O$. oleaster at sites H and D1 i.e. between 89 and $92 \%$. In contrast, O. oleaster plants growing in sites D2 and D3 had RWC's as low as 70 to $72 \%$. A progressive decrease in RWC was recorded in Q. coccifera plants from site H (May) to site D2.
Interestingly, plants growing at site D3 (the most degraded site) had higher RWC's (about 87\%) with respect to those recorded in plants growing at less degraded sites.

In figure 6, pre-dawn leaf water potential $\left(\Psi_{\text {pd }}\right)$ as well as $\Psi_{\min }$ are illustrated for the three species studied. It can be noted that $O$. oleaster plants showed progressively lower values of both $\Psi_{\mathrm{pd}}$ and $\Psi_{\text {min }}$ at sites $H$ to D3, with the only exception of $\Psi_{\mathrm{pd}}$ measured in plants growing at site D3 where $\Psi_{\mathrm{pd}}$ in September was very similar to that recorded at site $\mathrm{H}$ in the same month. The maximum decrease in $\Psi_{\mathrm{L}}$ (i.e. $\Psi_{\mathrm{pd}}-\Psi_{\min }$ ) was recorded in leaves of plants growing in site D3 and was impressive with a diurnal $\Delta \Psi$ of $4 \mathrm{MPa}\left(\Psi_{\mathrm{pd}}=-2.5 \mathrm{MPa}\right.$ and $\left.\Psi_{\text {min }}=-6.5 \mathrm{MPa}\right)$. In $C$. siliqua, $\Psi_{\mathrm{pd}}$ was about $-0.6 \mathrm{MPa}$ in May (site $\mathrm{H}$ ) and decreased to $-1.2 \mathrm{MPa}$ at sites H, D1 and D2 (September), and further to $-1.7 \mathrm{MPa}$ at site D3. For $C$. siliqua, $\Psi_{\min }$ ranged between $-1.8 \mathrm{MPa}$ at site $\mathrm{H}$ and $-3.0 \mathrm{MPa}$ at site D3. In $Q$. coccifera, $\Psi_{\mathrm{pd}}$ changed similarly to that in $C$. siliqua except for plants growing at site D3 where $\Psi_{\mathrm{pd}}$ was consistently more negative. Surprisingly, $\Psi_{\min }$ recorded in $Q$. coccifera dropped to $-2.8 \mathrm{MPa}$ in site $\mathrm{H}$ (September) with a $\Delta \Psi$ of 1.4 MPa.

It is of interest to note that the degraded sites were warmer and drier than site H. In September 1998, maximum air temperatures recorded during the measurements were $28.9,32.4,34.5$ and $35.4{ }^{\circ} \mathrm{C}$ in sites $\mathrm{H}, \mathrm{D} 1, \mathrm{D} 2$ and D3, respectively. Minimum air relative humidity was 36.4, 34.2, 25.9 and 16.6 in sites H, D1, D2 and D3, respectively.

\subsection{Impact of water stress on single species (WSIS) and vegetation (WSIV)}

The integrals of the curves describing the diurnal pattern of $\Psi_{\mathrm{L}}$ change (WSIS) calculated for the three species at the different study sites, are shown in figure 7. The calculated WSIS's were similar for the three species in May, i.e. between 10 and $17 \mathrm{MPa}$ h. In September, WSIS's distinctly increased, especially in $Q$. coccifera and $O$. oleaster (to 25 and $32 \mathrm{MPa}$ h, respectively). $O$. oleaster plants showed impressively increasing impacts of water stress in more degraded areas (sites D) with respect to those growing in the reference site $\mathrm{H}$.

When $\Psi_{\mathrm{pd}}, \Psi_{\min }$ and $\Delta \Psi\left(=\Psi_{\mathrm{pd}}-\Psi_{\min }\right)$, were plotted versus WSIS, linear relationships were observed (figure 8). The correlation between $\Delta \Psi$ and WSIS was the poorest $\left(r^{2}=0.44\right)$, with increased scatter of data at high WSIS values. The best correlation was found between $\Psi_{\min }$ and WSIS $\left(r^{2}=0.99\right)$ whereas the correlation between $\Psi_{\mathrm{pd}}$ and WSIS was intermediate $\left(r^{2}=0.75\right)$. 

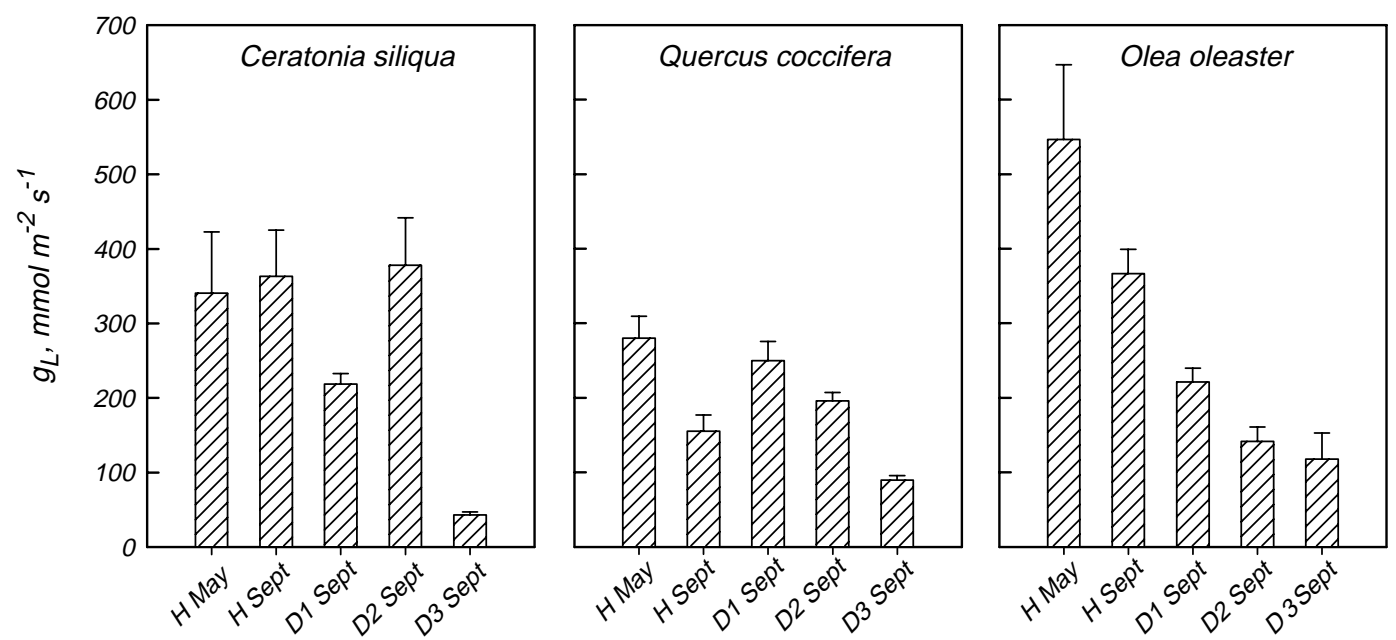

Figure 4. Maximum diurnal leaf conductance to water vapour $\left(\mathrm{g}_{\mathrm{L}}\right)$ as recorded in the well developed vegetation site $(\mathrm{H})$ in $\mathrm{May}$ and September 1998 and in degraded sites in September 1998.
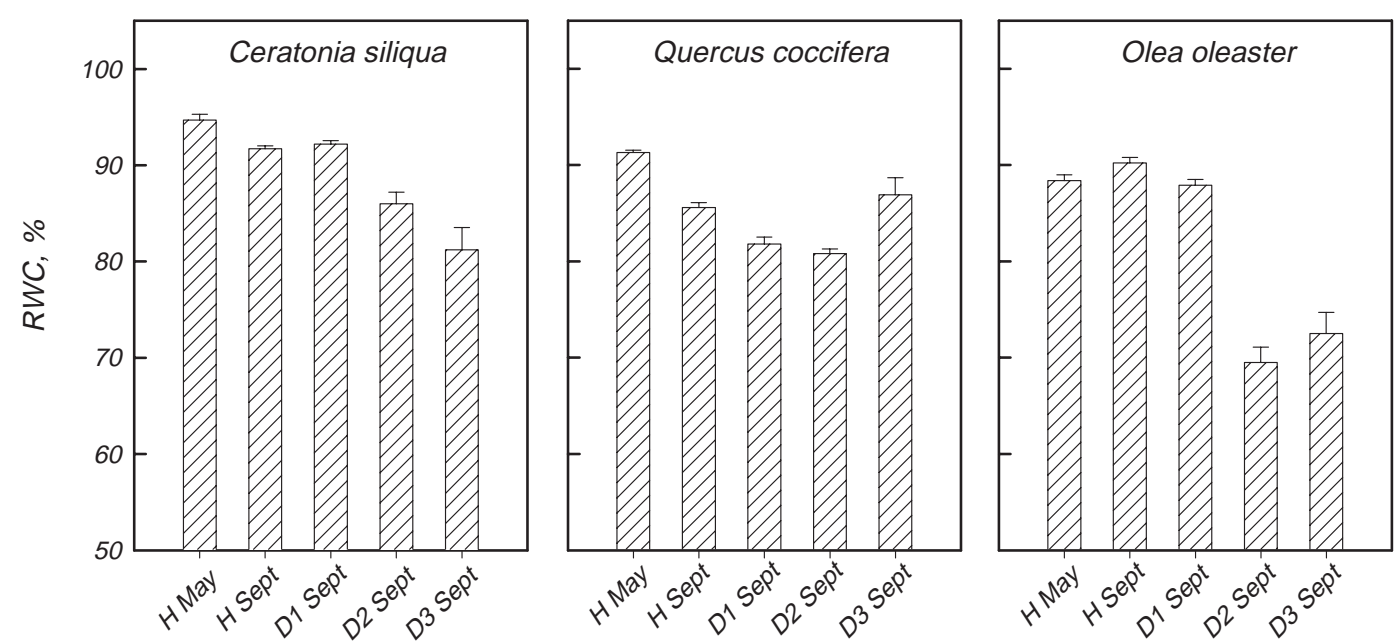

Figure 5. Minimum leaf relative water content (RWC) as recorded in the well developed vegetation site (H) in May and September 1998 and in degraded sites in September 1998.

The WSIV values (water stress impact weighed for the relative frequencies of the three species studied), calculated for the four study sites in September 1998, are illustrated in figure 9. Vegetation at sites $\mathrm{H}$ and D1 had the lowest water stress (WSIV was about $50 \mathrm{MPA}$ h); WSIV increased for vegetation growing at sites D2 and D3 (up to about $90 \mathrm{MPa}$ h).
When the WSIV's calculated for all the sites under study were plotted versus NDVI values (figure 10a), an exponential relationship was noted between the two variables $\left(r^{2}=0.95\right)$. The correlation between WSIV and the estimated vegetation cover of the four sites was highly significant $\left(r^{2}=0.963\right)$ (figure 10b). 

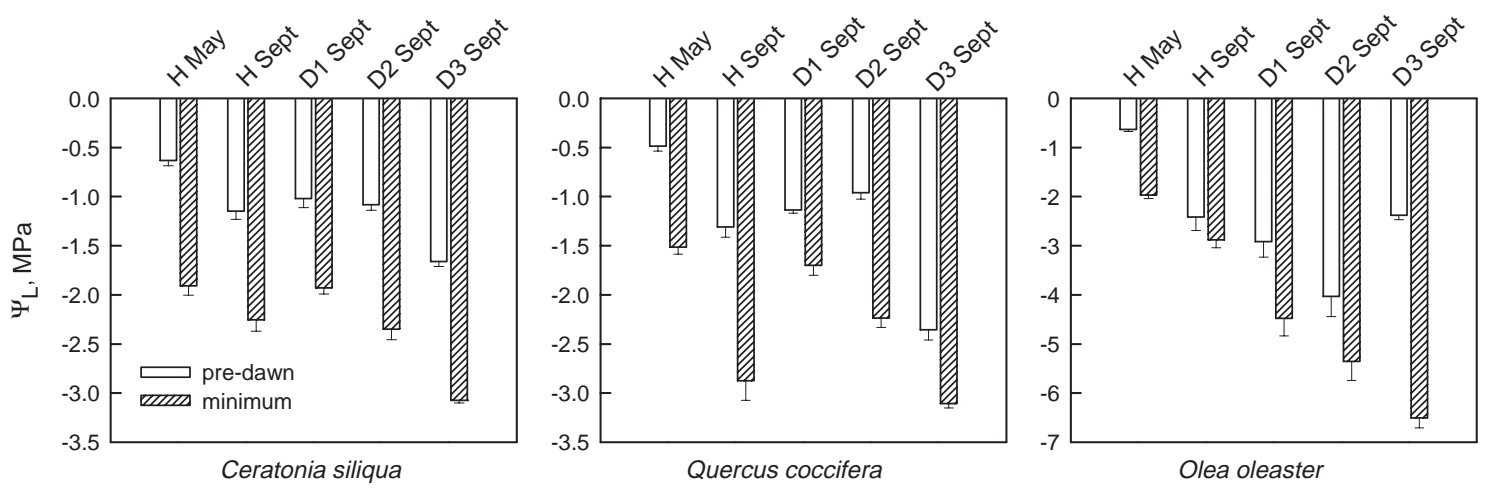

Figure 6. Predawn and minimum diurnal leaf water potential $\left(\Psi_{L}\right)$ as recorded in the well developed vegetation site $(H)$ in May and September 1998 and in degraded sites in September 1998.
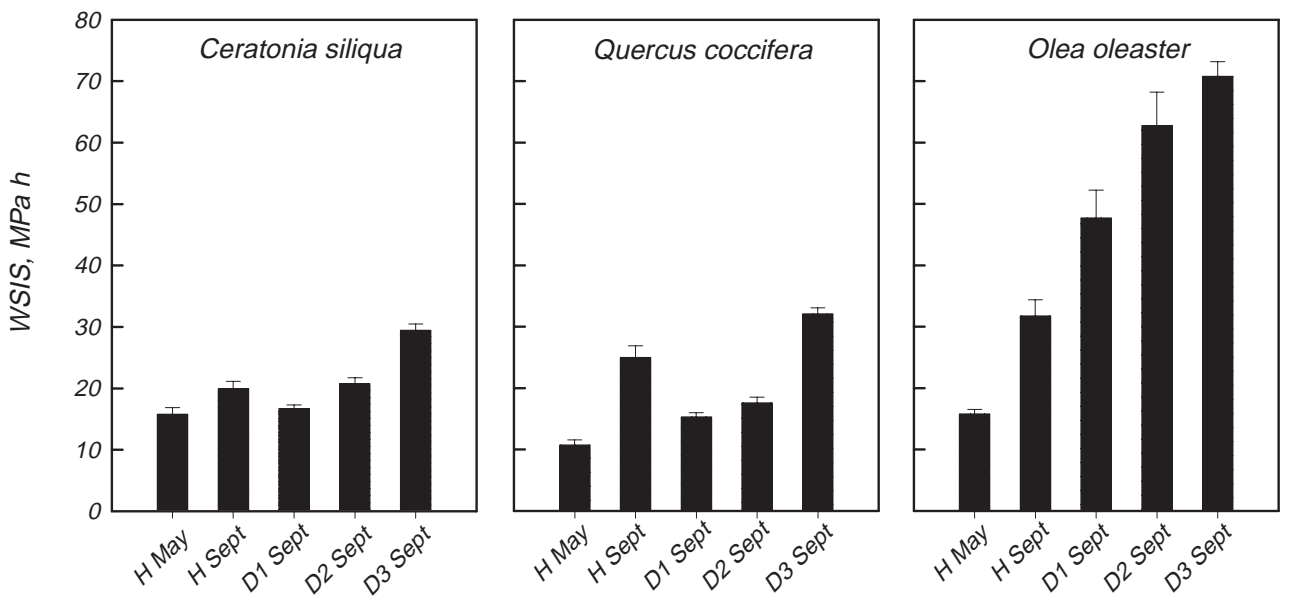

Figure 7. Water Stress Impact on Species (WSIS) calculated as the integral of the diurnal time course of leaf water potential between predawn and sunset, as recorded in the well developed vegetation site $(\mathrm{H})$ in May and September 1998 and in degraded sites in September 1998.

\section{DISCUSSION}

The close relationship observed between the directly estimated and the remotely sensed vegetation cover (figure 3) suggests that NDVI was a sufficiently reliable expression of vegetation density or leaf area in the four sites under study. Because NDVI is a measure of the reflectance of the red wavelengths by vegetation, it is related to the total photosynthetic surface area $(\mathrm{PhA})$. Therefore, NDVI is sensitive to the dominant growth form (grass, shrubs or trees) in an area. As an example, at equal vegetation covers, a forest will show more $\mathrm{PhA}$ than a shrub or grass vegetation so that NDVI will be much higher in the former than in the latter case [7, 46]. This helps to explain why at 76 to $78 \%$ vegetation cover as estimated in sites $\mathrm{H}$ and D1, respectively, NDVI was almost double in site $\mathrm{H}(0.615)$ with respect to site D1 (0.317). Site H was dominated by trees whereas site D1 was dominated by shrubs. In other words, NDVI can be conveniently used in cases of different vegetation densities with similar dominant growth forms but requires to be corrected for large differences in this variable. 

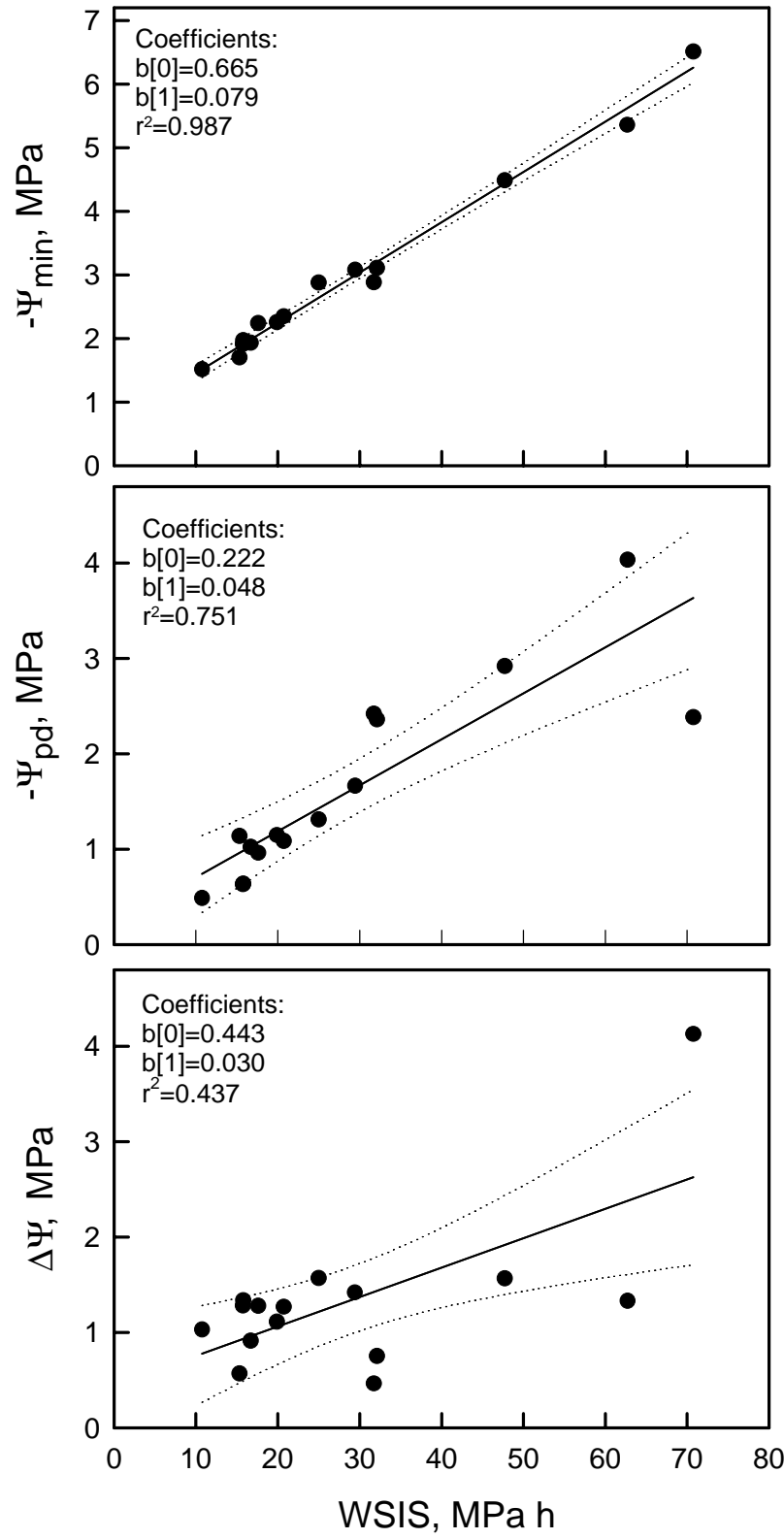

Figure 8. Relationships between minimum leaf water potential $\left(\Psi_{\text {min }}\right)$, predawn leaf water potential $\left(\Psi_{\mathrm{pd}}\right)$, maximum diurnal leaf water potential drop $\left(\Delta \Psi=\Psi_{\text {pd }}-\Psi_{\text {min }}^{\text {pd }}\right)$ and Water Stress Impact on Species (WSIS) calculated for all the species under study on the basis of equation (2). Solid lines are the linear regressions and the dotted curves are the $95 \%$ confidence intervals.

In previous studies [18, 19, 48], C. siliqua growing in Sicily has been reported to behave like a typical drought avoiding water spender [15]. A similar drought resis- tance strategy was adopted by this species growing in Turkey in that plants combined high maximum $\mathrm{g}_{\mathrm{L}}$ 's ( figure 4) with high RWC's (between 86 and 92\%, figure 5) as recorded in sites H, D1 and D2, and by relatively constant $\Psi_{\text {min }}$ 's and $\Psi_{\text {pd }}$ 's as measured in the same sites. This suggests that plants lost relatively large amounts of water (high $g_{\mathrm{L}}$ ); however, leaves were able to maintain relatively high RWC even in the warmest hours of the day so that $\Psi_{\min }$ was buffered to relatively constant values. A typical water spender is defined as a species capable of maintaining hydraulic equilibrium between water loss and uptake $[15,18,26]$. In this sense, $C$. siliqua behaved like a very efficient water spender. In the most degraded site (D3), however, C. siliqua was no longer capable of compensating for water loss. An almost complete stomatal closure $\left(g_{\mathrm{L}}\right.$ dropped to $50 \mathrm{mmol} \mathrm{m}^{-2} \mathrm{~s}^{-1}$ ) could not prevent a further decrease in RWC (to $82 \%$ ) causing $\Psi_{\min }$ to drop to $-3.0 \mathrm{MPa}$. Under these conditions, C. siliqua switched to a water saving strategy [15]. The consistent decrease of the frequency of the species in sites D1 and D2, however, combined with the healthy aspect of existing plants as well as with their high RWC's and $g_{\mathrm{L}}$ 's, suggests that other factors like soil nutrient content or wind could have limited the spatial expansion of $C$. siliqua.

Species belonging to the genus Quercus are generally considered as drought resistant as a group [1]. Several studies have shown that different Quercus species can adopt quite different resistance strategies to withstand water shortage $[2,25,26,30,49]$. Nonetheless, the most common strategy adopted by Quercus sp. to withstand aridity is drought avoidance based on water saving. This appeared to be true also in the case of $Q$. coccifera growing in different areas of Turkey. In fact, when growing in degraded sites, this species reduced $g_{\mathrm{L}}$, thus maintaining high RWC's (over $80 \%$ ) and preventing $\Psi_{\mathrm{L}}$ to drop to critical values. A similar strategy was reported by Lösch et al. [20] for $Q$. coccifera plants growing in Portugal. It is worth noting that a partial stomatal closure was sufficient to reduce water loss in this species. In fact, plants growing in the most degraded site (D3) were able to maintain RWC's at similar levels with respect to those recorded in site $\mathrm{H}$, by reducing $g_{\mathrm{L}}$ by only about $60 \%$. In turn, $\Psi_{\min }$ never dropped beyond about $-3.0 \mathrm{MPa}$, a value similar to $\Psi_{\mathrm{L}}$ levels recorded in C. siliqua. $Q$. coccifera was very competitive in degraded areas where this species increased its relative frequency by about $50 \%$ and, in fact, became dominant in sites D2 and D3 (table I). The competitiveness of $Q$. coccifera in degraded areas might well be also due to ability to resprout after fire or severe grazing.

$O$. oleaster plants appeared to be unable to prevent dehydration in spite of consistent decrease of $g_{\mathrm{L}}$, when 
subjected to increasing water stress. Stomatal closure, in fact, was not sufficient to prevent water loss and RWC dropped to about $70 \%$ in the most degraded sites (D2 and D3). Accordingly, $\Psi_{\mathrm{L}}$ reached very negative values (down to $-6.8 \mathrm{MPa}$ in site D3, figure 6), i.e. well below the turgor loss point reported for this species by Lo Gullo and Salleo [18] and by Duhme and Hinckley [9]. Because $O$. oleaster maintained its relative frequency approximately the same for site D3 as for the other sites (table I), on the basis of our data and in accordance with previous reports $[12,18,50]$, this species can be regarded as a drought tolerant species [15].

It has been suggested $[25,26,56]$ that the capability of a given species to maintain high root hydraulic conductance might represent one of the most important factors in determining the drought resistance strategy that can be adopted by the species. In other words, the water spending strategy as adopted by $C$. siliqua, would be only possible if a sufficient amount of water can be extracted from the soil and conducted to the leaves even during the dry periods. This was likely to be the case for C. siliqua, on the basis of a study by Nardini, Salleo and Lo Gullo [27] conducted on $C$. siliqua plants growing in Sicily. Here, plants were able to maintain or even increase the hydraulic efficiency of the root system during summer. In contrast, the root system of O. oleaster proved to be extremely vulnerable to drought due to a large reduction in root hydraulic conductance as measured in this species when exposed to drought stress [17, 27]. These results explain why $O$. oleaster, when growing in arid sites, underwent consistent dehydration even at quite low $g_{\mathrm{L}}$ levels. This, in turn, would cause a proportional reduction in gas exchange and, hence, in biomass production.

Calculating the integral of diurnal $\Psi_{L}$ changes for the three study species, proved to be a useful method to assess the impact of water stress on these species (figure 7). In particular, WSIS did not increase substantially in plants of $C$. siliqua and $Q$. coccifera growing at sites D1 and D2 versus those at site $\mathrm{H}$. This suggested that these species were able to limit the negative effects of water shortage. Plants of $C$. siliqua and $Q$. coccifera growing on the most degraded site (D3), however, were under water stress and WSIS increased, accordingly. In contrast, WSIS calculated for $O$. oleaster increased markedly from site $\mathrm{H}$ to site D3; this species was unable to prevent the negative effects of prolonged water shortage.

Measurement of changes in water relations parameters and, especially, WSIS suggested that $C$. siliqua and $Q$. coccifera are species well adapted to aridity as induced by environmental degradation. As a consequence, both $C$. siliqua and $Q$. coccifera can be considered as suitable candidates to natural reforestation of degraded areas of the Mediterranean Basin region. Moreover, Carob tree is a species of increasing economic interest for industrial use of seeds and fruits $[10,35,61,62]$. Although $O$. oleaster was very sensitive to aridity, this species was a suitable indicator of the degree of degradation of the different areas under study and, hence, it could be conveniently used as a "field biomonitor" [34, 40].

When comparing WSIS to some of the most commonly used $\Psi_{\mathrm{L}}$ reference parameters (i.e. $\Psi_{\min }, \Psi_{\mathrm{pd}}$ and $\Delta \Psi$ ), the best correlation existed between WSIS and $\Psi_{\min }$. It should be noted, however, that $\Psi_{\min }$ was calculated as the mean of $\Psi_{\mathrm{L}}$ levels recorded during the warmest hours of the day (i.e. between 10:00 and 14:00) and not as the minimum diurnal $\Psi_{\mathrm{L}}$ as measured at one point in the day as more typically done. Some Mediterranean species such as Laurus nobilis L. [18] reach a minimum diurnal $\Psi_{\mathrm{L}}$ that is maintained for less than one hour i.e. $\Psi_{\mathrm{L}}$ raises again quite rapidly. In this case, $\Psi_{\min }$ may not be the true expression of the impact of water stress on a plant. Therefore, we feel that the most reliable method to assess the impact of water stress on different species is to measure the whole curve of $\Psi_{\mathrm{L}}$ diurnal changes and then calculating WSIS on the basis of equation (2).

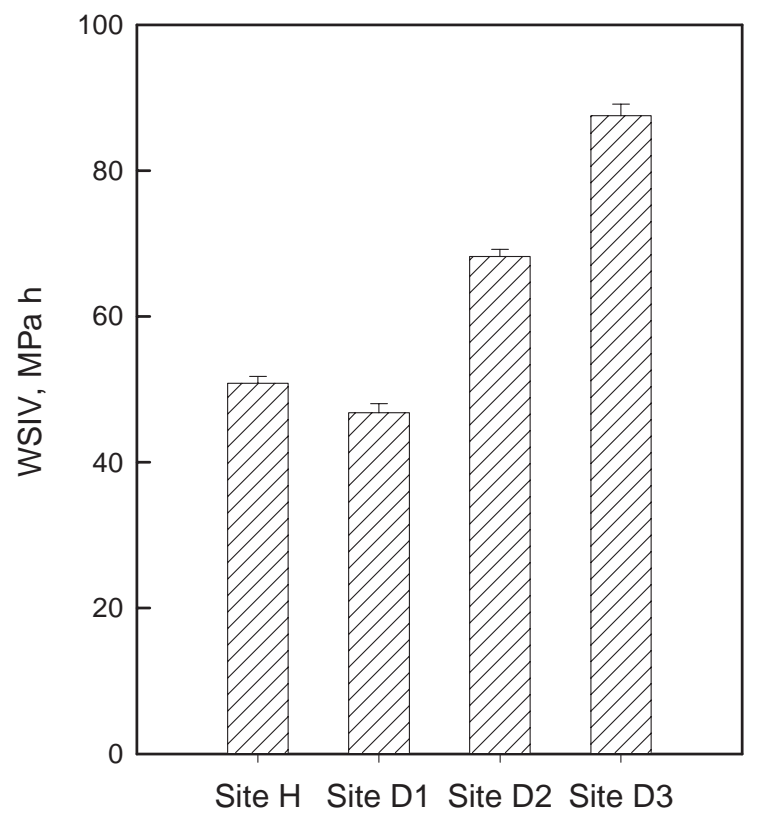

Figure 9. Water Stress Impact on Vegetation (WSIV) calculated on the basis of equation (4) as the sum of the Water Stress Impact on Species (WSIS) measured in September 1998, times the species relative frequency. Sites are labelled as $\mathrm{H}$ (well developed vegetation site), D1, D2 and D3 (degraded sites). 

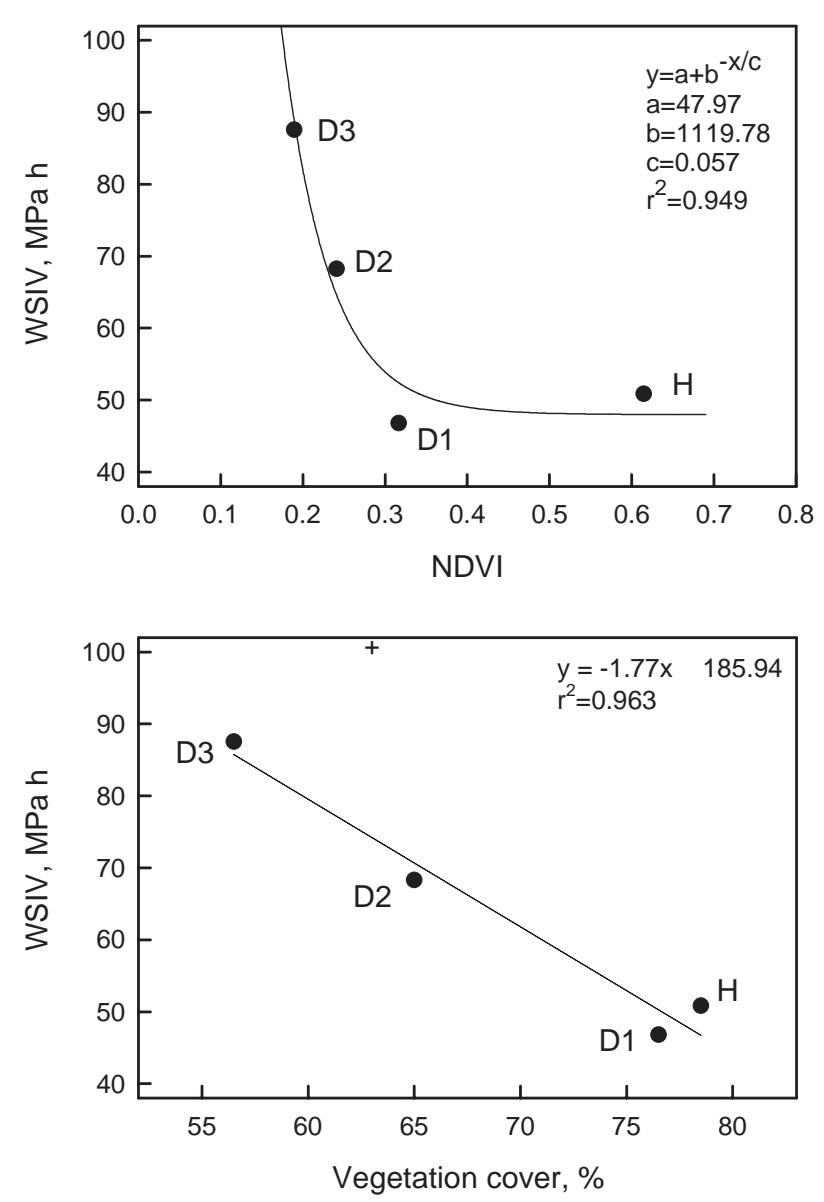

Figure 10. Relationship between Water Stress Impact on Vegetation (WSIV), Normalized Difference Vegetation Index (NDVI) and percentage vegetatio cover. The regressions are reported toghether with the correlation coefficient $r^{2}$. Sites are labelled as H (well developed vegetation site), D1, D2 and D3 (degraded sites).

In our opinion, an interesting result emerging from the present study is the possibility of scaling up the impact of water stress from the single-species level to the level of vegetation as represented by one or more selected dominant species i.e. calculating WSIV on the basis of equation (4). In our case, WSIV (figure 9) was very similar for species growing at sites $\mathrm{H}$ and D1, but it increased significantly for more degraded sites (WSIV increased by 36 and $76 \%$ for species growing in sites D2 and D3, respectively).

Recent ecological research has related the amount of different abiotic stresses suffered by plants to remotely sensed features of vegetation $[4,28,36,37,38,41,44$,
63]. In the present study, the possibility of using field measurements of leaf water potential as a tool for relating the amount of water stress suffered by vegetation to simple satellite-derived indices, like NDVI, was investigated. A negative, exponential relationship appeared to exist between WSIV and NDVI (figure 10a) whereas a linear relationship was noted between WSIV and percent vegetation cover (figure 10b). In particular, our data suggest, at least for Mediterranean sclerophyllous vegetation growing in coastal regions of Turkey, that NDVI's smaller than about 0.3 indicate a critical transition point in vegetation status below which the risk of desertification increases dramatically and that, therefore, such areas need to be monitored more frequently and accurately and, if possible, promptly restored.

We are aware that the small number of the sites studied (only four sites) does not provide a fully adequate evaluation of a number of the relationships explored in this study. In this view, our results have to be seen as a preliminary approach to the problem. Nonetheless, the close relationship of WSIV to NDVI appears sufficiently promising to deserve more studies. Such studies might include: a) more sites per region, in order to confirm the validity of equation (4); b) a more comprehensive evaluation of growth form, density and leaf area index.

Acknowledgements: The present study was funded by EU in the frame of the project entitled: "Desertification in Mediterranean Drylands: Development of a monitoring System based on Plant Ecophysiology" (DEMOS, Contract No. IC18-CT970153).

\section{REFERENCES}

[1] Abrams M.D., Adaptations and responses to drought in Quercus species of North America, Tree Physiol. 7 (1990) 227-238.

[2] Acherar M., Rambal S., Comparative water relations of four Mediterranean oak species, Vegetatio 99/100 (1992) 177-184.

[3] Améglio T., Archer P., Cohen M., Valancogne C., Daudet F.A., Dayau S., Cruiziat P., Significance and limits in the use of predawn leaf water potential for tree irrigation, Plant Soil 207 (1999) 155-167.

[4] Baret F., Use of spectral reflectance variation to retrieve canopy biophysical characteristics, in: Danson F.M., Plummer S.E. (Eds.), Advances in Environmental Remote Sensing, John Wiley \& Sons, New York, 1995, pp. 33-51.

[5] Benyon R.G., Nighttime water use in an irrigated Eucalyptus grandis plantation, Tree Physiol. 19 (1999) 853-859.

[6] Bond B.J., Kavanagh K.L., Stomatal behavior of four woody species in relation to leaf-specific hydraulic 
conductance and threshold water potential, Tree Physiol. 19 (1999) 503-510.

[7] Danson F.M., Developments in the remote sensing of forest canopy structure, in: Danson F.M., Plummer S.E. (Eds.), Advances in Environmental Remote Sensing, John Wiley \& Sons, New York, 1995, pp. 53-69.

[8] Donovan L.A., Grisé D.J., West J.B., Pappert R.A., Alder N.N., Richards J.H., Predawn disequilibrium between plant and soil water potentials in two cold-desert shrubs, Oecologia 120 (1999) 209-217.

[9] Duhme F., Hinckley T.M., Daily and seasonal variation in water relations of macchia shrubs and trees in France (Montpellier) and Turkey (Antalya), Vegetatio 99/100 (1992) 185-198.

[10] Fenaroli L., Guida agli Alberi d'Italia, Giunti Martello, Firenze, 1984.

[11] Fischer R.A., Turner N.C., Plant productivity in the arid and semiarid zones, Ann. Rev. Pl. Physiol. Pl. Mol. Biol. 29 (1978) 277-317.

[12] Giorio P., Sorrentino G., d'Andria R., Stomatal behaviour, leaf water status and photosynthetic response in fieldgrown olive trees under water deficit, Environ. Exp. Bot. 42 (1999) 95-104.

[13] Grove A.T., Desertification in Southern Europe, Clim. Change 9 (1986) 49-57.

[14] Hardegree S.P., Xylem water holding capacity as a source of error in water potential estimates made with the pressure chamber and thermocouple psychrometer, Am. J. Bot. 76 (1989) 356-360.

[15] Levitt J., Responses of Plants to Environmental Stresses, Academic Press, New York, 1980.

[16] Lillesand T.M., Kiefer R.W., Remote Sensing and Image Interpretation, John Wiley \& Sons, New York, 1994.

[17] Lo Gullo M.A., Nardini A., Salleo S., Tyree M.T., Changes in root hydraulic conductance $\left(\mathrm{K}_{\mathrm{R}}\right)$ of Olea oleaster seedlings following drought stress and irrigation, New Phytol. 140 (1998) 25-31.

[18] Lo Gullo M.A., Salleo S., Different strategies of drought resistance in three Mediterranean sclerophyllous trees growing in the same environmental conditions, New Phytol. 108 (1988) 267-276.

[19] Lo Gullo M.A., Salleo S., Rosso R., Drought avoidance strategy in Ceratonia siliqua L., a mesomorphic-leaved tree in the xeric Mediterranean area, Ann. Bot. 58 (1986) 745-756.

[20] Lösch R., Tenhunen J.D., Pereira J.S., Lange O.L., Diurnal courses of stomatal resistance and transpiration of wild and cultivated Mediterranean perennials at the end of the summer dry season in Portugal, Flora 172 (1982) 138-160.

[21] Margaris N.S., Koutsidou E., Giourga C., Changes in traditional Mediterranean land-use systems, in: Brandt J., Thornes J.B. (Eds.), Mediterranean Desertification and Land Use, John Wiley \& Sons, New York, 1996, pp. 29-42.

[22] Mather P.M., Computer Processing of RemotelySensed Images, John Wiley \& Sons, New York, 1987.
[23] Mishio M., Yokoi Y., A model for estimation of water flow resistance in soil-leaf pathway under dynamic conditions, J. Exp. Bot. 42 (1991) 541-546.

[24] Mooney H.A., Habitat, plant form, and plant water relations in Mediterranean-climate regions, Ecol. Med. 8 (1982) 481-488.

[25] Nardini A., Lo Gullo M.A., Salleo S., Competitive strategies for water availability in two Mediterranean Quercus species, Plant Cell Environ. 22 (1999) 109-116.

[26] Nardini A., Pitt F., Drought resistance of Quercus pubescens as a function of root hydraulic conductance, xylem embolism and hydraulic architecture, New Phytol. 143 (1999) 485-493.

[27] Nardini A., Salleo S., Lo Gullo M.A., Root hydraulic conductance of six forest trees: possible adaptive significance of seasonal changes, Pl. Biosys. 132 (1998) 97-104.

[28] Nemani R., Pierce L.L., Running S.W., Goward S., Developing satellite-derived estimates of surface moisture status, J. Appl. Meteor. 32 (1993) 548-556.

[29] Nilsen E.T., Orcutt D.M., The Physiology of Plants under Stress, John Wiley \& Sons, New York, 1996.

[30] Oliveira G., Correia O.A., Martins-Louçao M.A., Catarino F.M., Water relations of cork-oak (Quercus suber L.) under natural conditions, Vegetatio 99/100 (1992) 199-208.

[31] Ozturk M., Recovery and rehabilitation of Mediterranean type ecosystems: a case study from Turkish maquis, in: Rapport D., Gaudet C.L., Calow P. (Eds.), Evaluating and Monitoring the Health of Large-Scale Ecosystems, Springer Verlag, Berlin, 1995, pp. 319-332.

[32] Ozturk M., Urban ecology and land degradation, in: Farina A. (Ed.), Perpectives in Ecology, Backhuys Publishers, Leiden, 1999, pp. 115-120.

[33] Ozturk M., Celik A., Nurlu E., Erdem U., Land degradation in relation to urbanisation and industrialisation in the West Anataolian region of Turkey, in: Kapur S. (Ed.), International Conference on Land Degradation, Cukurova University, Adana, 1996, p. 62.

[34] Ozturk M., Secmen O., Kondo K., Transpirational studies on some macchia elements, Mem. Fac. Integ. Arts Sci. Hirosh. Univ. 8 (1983) 68-76.

[35] Ozturk M., Vardar Y., Chemical composition of Carob seed, Phyton 33 (1975) 63-64.

[36] Peñuelas J., Filella I., Visible and near-infrared reflectance techniques for diagnosing plant physiological status, Trends Pl. Sci. 3 (1998) 151-156.

[37] Peñuelas J., Inoue Y., Reflectance indices indicative of changes in water and pigment contents of peanut and wheat leaves, Photosynthetica 36 (1999) 355-360.

[38] Pierce L.L., Running S.W., Riggs G.A., Remote detection of canopy water stress in coniferous forests using the NS001 thematic mapper simulator and the thermal infrared multispectral scanner, Photogram. Engin. Rem. Sens. 56 (1990) 579-586.

[39] Plummer S.E., Danson F.M., Wilson A.K., Advances in remote sensing technology, in: Danson F.M., Plummer S.E. 
(Eds.), Advances in Environmental Remote Sensing, John Wiley \& Sons, New York, 1995, pp. 1-7.

[40] Powell R.L., The use of vascular plants as "field" biomonitors, in: Wang W., Gorsuch J.W., Hughes J.S. (Eds.), Plants for Environmental Studies, Lewis Publishers, New York, 1997, pp. 335-365.

[41] Purevdorj T., Tateishi R., Ishiyama T., Honda Y. (1998) Relationships between percent vegetation cover and vegetation indices, Int. J. Rem. Sens. 19 (1998) 3519-3535.

[42] Richter H., The water status in the plant. Experimental evidence, in: Lange O.L., Kappen L., Schulze E.D. (Eds.), Water in Plant Life. Ecological Studies 19, Springer Verlag, Berlin, 1976, pp. 42-58.

[43] Richter H., Water relations of plants in the field: some comments on the measurement of selected parameters, J. Exp. Bot. 48 (1997) 1-7.

[44] Riggs G.A., Running S.W., Detection of canopy water stress in conifers using the airborne imaging spectrometer, Rem. Sens. Environ. 35 (1991) 51-68.

[45] Ritchie G.A., Hinckley T.M., The pressure chamber as an instrument for ecological research, Adv. Ecol. Res. 9 (1975) $165-254$.

[46] Running S.W., Estimating terrestrial primary productivity by combining remote sensing and ecosystem simulation, in: Hobbs R.J., Mooney H.A. (Eds.), Remote Sensing of Biosphere Functioning, Springer Verlag, New York, 1990, pp. $65-86$.

[47] Salleo S., Water relations parameters of two Sicilian species of Senecio (Groundsel) measured by the pressure bomb technique, New Phytol. 95 (1983) 178-188.

[48] Salleo S., Lo Gullo M.A., Different aspects of cavitation resistance in Ceratonia siliqua, a drought-avoiding Mediterranean tree, Ann. Bot. 65 (1989) 259-270.

[49] Salleo S., Lo Gullo M.A., Sclerophylly and plant water relations in three Mediterranean Quercus species, Ann. Bot. 65 (1990) 259-270.

[50] Salleo S., Lo Gullo M.A., Drought resistance strategies and vulnerability to cavitation of some Mediterranean sclerophyllous trees, in: Borghetti M., Grace J., Raschi A. (Eds.), Water Transport in Plants under Climatic Stress, Cambridge University Press, Cambridge, 1993, pp. 99-113.
[51] Salleo S., Nardini A., Lo Gullo M.A., Is sclerophylly of Mediterranean evergreens and adaptation to drought? New Phytol. 135 (1997) 603-612.

[52] Salleo S., Nardini A., Lo Gullo M.A., Pitt F., Xylem cavitation and hydraulic control of stomatal conductance in Laurel (Laurus nobilis L.), Plant Cell Environ. 23 (2000) 71-79.

[53] Stirzaker R.J., Passioura J.B., The water relations of the root-soil interface, Plant Cell Environ. 19 (1996) 201-208.

[54] Stoms D.M., Hargrove W.W., Potential NDVI as a baseline for monitoring ecosystem functioning, Int. J. Remote Sens. 21 (2000) 401-407.

[55] Stuart Chapin III F., Integrated responses of plants to stress, Bioscience 41 (1991) 29-36.

[56] Terradas J., Savé R., The influence of summer and winter stress and water relationships on the distribution of Quercus ilex L., Vegetatio 99/100 (1992) 137-145.

[57] Thornes J.B., Introduction, in: Brandt J., Thornes J.B. (Eds.), Mediterranean Desertification and Land Use, John Wiley \& Sons, New York, 1996, pp. 1-11.

[58] Tyree M.T., Ewers F.W., The hydraulic architecture of trees and other woody plants, New Phytol. 119 (1991) 345-360.

[59] Tyree M.T., Hammel H.T., The measurement of the turgor pressure and water relations of plants by the pressure bomb technique, J. Exp. Bot., 23 (1972) 267-282.

[60] Tyree M.T., Karamanos A.J., Water stress as an ecological factor, in: Grace J., Ford E.D., Jarvis P.G. (Eds.), Plants and their Atmospheric Environment, Blackwell, Oxford, 1980, pp. 237-261.

[61] Vardar Y., Secmen O., Ozturk M., Preliminary results on the chemical composition of the Turkish carob beans, Qual. Plant. Mat. Veget. 21 (1972) 367-379.

[62] Vardar Y., Secmen O., Ozturk M., Some distributional problems and biological characteristics of Ceratonia in Turkey, Acta Biol. Portug. 16 (1980) 75-86.

[63] Waring R.H., Lessons learned while extending physiological principles from growth chambers to satellite studies, Tree Physiol. 18 (1998) 491-497. 